\title{
AGENDA SETTING PENGELOLAAN SAMPAH PASAR DI KOTA MAKASSAR
}

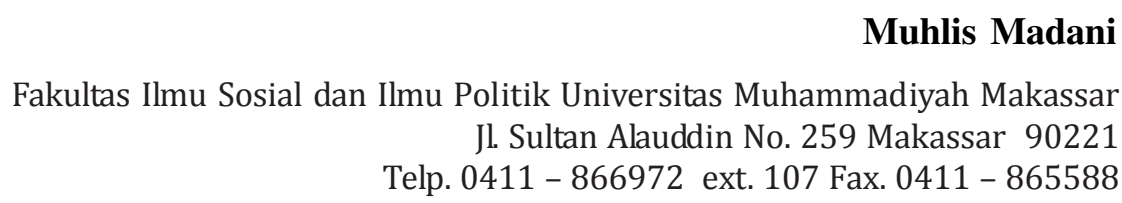

\section{ABSTRAK}

$\Delta$ wal munculnya isu pengelolaan sampah pasar ini dimulai dari adanya problem kebersihan, keteraturan, kenyamanan, dan keamanan untuk berbelanja di pasar tradisional, yang berkembang di tengah-tengah masyarakat. Adapun problem isu di sini, masyarakat pengguna pasar tradisional mempunyai anggapan adanya kejenuhan terhadap kinerja pemerintah daerah, di samping itu masyarakat menginginkan adanya suatu perubahan yang dapat menyentuh aspek manajemen dan teknis pengelolaan sampah pasar.

Pemerintah Kota Makassar mesti melakukan pembenahan serius terhadap fasilitas persampahan, terutama pada kondisi pasar pasca-revitalisasi. Sistem dan penyediaan fasilitas tersebut melibatkan partisipasi pedagang. Pendekatan secara partisipatif dalam perencanaan, pengadaan dan pemeliharaan fasilitas akan meningkatkan rasa memiliki di kalangan pedagang pasar. Untuk itulah penyusunan agenda kebijakan pengelolaan sampah pasar penting untuk dilakukan.

Rancangan Peraturan Daerah (Ranperda) tentang penataan Pasar Tradisional perlu dipercepat pembahasan dan atau pemberlakuannya, terutama hal yang berkaitan dengan sistem dan prosedur pengelolaan sampah pasar. Gagasan dan kebijakan revitalisasi pasar tradisional diharapkan tidak hanya terfokus pada aspek penataan spasial (keruangan), tetapi juga memperhatikan aspek sosial dan pengelolaan lingkungan terutama aspek persampahan.

Kata Kunci : isu, agenda, agenda setting, sampah pasar

\section{A. PENDAHULUAN}

\section{1) Latar Belakang.}

Sampah pada umumnya dianggap sebagai benda yang tidak berguna, kompleks seiring dengan berkembangnya aktivitas ekonomik. sehingga disikapi dengan kaidah not in my backyard (NIMBY). Pada prinsipnya jumlah

sampah akan meningkat seiring dengan meningkatnya aktivitas ekonomi. Selain jumlahnya, jenis dan dampak dari sampah juga semakin beragam, ketika dalam aktivitas ekonomik tersebut terlibat teknologi- 
teknologi baru. Misalnya, produksi bahanbahan transgenik akan menghasilkan sampah transgeni, produksi bahan radioaktif akan menghasilkan sampah radioaktif. Jadi, permasalahan sampah akan cenderung semakin kompleks seiring dengan berkembangnya aktivitas ekonomik.

Pertambahan jumlah penduduk, perubahan pola konsumsi, dan gaya hidup masyarakat telah meningkatkan jumlah, jenis, dan keberagaman karakteristik sampah. Meningkatnya daya beli masyarakat terhadap berbagai jenis bahan pokok dan hasil teknologi serta meningkatnya usaha atau kegiatan penunjang pertumbuhan ekonomi suatu daerah juga memberikan kontribusi yang besar terhadap kuantitas dan kualitas sampah yang dihasilkan. Meningkatnya volume sampah memerlukan pengelolaan. Pengelolaan sampah yang tidak mempergunakan metode dan teknik pengelolaan sampah yang ramah lingkungan selain akan dapat menimbulkan dampak negatif terhadap kesehatan juga akan sangat mengganggu kelestarian fungsi lingkungan baik lingkungan pemukiman, hutan, persawahan, sungai dan lautan.

Sebuah pendekatan pengelolaan sampah yang konvensional, yang masih umum dipraktikkan, adalah yang bersifat pasif, instruksional dengan penekanan pada pengolahan sampah diujung proses produksi ekonomik (dikenal sebagai endof pipe approach). Pengelolaan sampah dengan pendekatan seperti ini tidak mendorong terjadinya inovasi dalam aktivitas ekonomik yang diperlukan untuk memasukkan nilai-nilai lingkungan dan keberlanjutan pembangunan ke dalam aktivitas tersebut. Pengelolaan sampah yang bersifat instruktif (top-down) juga kurang kondusif bagi terjadinya pembelajaran masyarakat.

Berdasarkan Undang-Undang No. 18 Tahun 2008, sampah adalah sisa kegiatan sehari-hari manusia dan/atau proses alam yang berbentuk padat. Pengelolaan sampah dimaksudkan adalah kegiatan yang sistematis, menyeluruh, dan berkesinambungan yang meliputi pengurangan dan penanganan sampah. Berdasarkan sifat fisik dan kimianya sampah dapat digolongkan menjadi: 1) sampah ada yang mudah membusuk terdiri atas sampah organik seperti sisa sayuran, sisa daging, daun dan lain-lain; 2) sampah yang tidak mudah membusuk seperti plastik, kertas, karet, logam, sisa bahan bangunan dan lainlain; 3) sampah yang berupa debu/abu; dan 4) sampah yang berbahaya (B3) bagi kesehatan, seperti sampah berasal dari industri dan rumah sakit yang mengandung zat-zat kimia dan agen penyakit yang berbahaya.

Pengelolaan sampah bertujuan untuk meningkatkan kesehatan masyarakat dan kualitas lingkungan serta menjadikan sampah sebagai sumber daya. Dari sudut pandang kesehatan lingkungan, pengelolaan sampah dipandang baik jika sampah tersebut tidak menjadi media berkembang biaknya bibit penyakit serta sampah tersebut tidak menjadi medium perantara menyebarluasnya suatu penyakit. Syarat lainnya yang harus dipenuhi, yaitu tidak mencemari udara, air dan tanah, tidak menimbulkan bau (tidak mengganggu nilai estetis), tidak menimbulkan kebakaran dan yang lainnya.

Ketika diamati dari berbagai rujukan dan pengalaman berbagai negara, permasalahan sampah sebenarnya berjalan seiring dengan kebudayaan masyarakat itu sendiri. Semakin maju tingkat penguasaan teknologi, industri dan kebudayaan suatu masyarakat, diduga sampah yang ditimbulkan semakin meningkat juga. Volume sampah yang besar dan beranekaragam jenisnya jika tidak dikelola dengan baik dan benar sangat berpotensi menimbulkan berbagai permasalahan lingkungan yang kompleks dan serius, antara lain: 1) pencemaran air oleh "lindi" (leachate) yang keluar dari tumpukan sampah dan mengalir menuju badan perairan ataupun meresap ke dalam tanah; 2) pencemaran udara karena adanya gas metana $\left(\mathrm{CH}^{4}\right)$, salah satu jenis gas rumah kaca, yang keluar dari tempat penimbunan akhir sampah akibat proses penguraian bahan organik secara anaerobik; 3) sampah merupakan habitat bagi berkembangnya bakteri patogen tertentu seperti Salmonella typhosa, Entamoeba coli, Escherichia coli, Vibrio cholera, Shigella dysentriae, Entamoeba histolytica, dan lain-lain yang dapat menimbulkan penyakit pada 
manusia; 4) menurunkan nilai estetika lingkungan; dan 5) mengurangi kenyamanan lingkungan.

Sampah telah menjadi masalah yang besar, bagi kota-kota besar di Indonesia seperti Jakarta, Surabaya, termasuk Makassar. Cakupan pelayanan pengelolaan persampahan yang masih rendah khususnya di perkotaan dapat berdampak pada meningkatnya wabah penyakit menular seperti tipus, kolera, muntaber, disentri, pes, leptospirus, salmonelosis, demam gigitan tikus. Selain itu, sampah yang dibuang ke kanal dan saluran pembuangan berpotansi menimbulkan banjir (Percik, Vol. 5 Tahun I/Agustus 2004).

Volume sampah di Makassar tahun 2004 tercatat 4.330 ton perhari, jumlah ini meningkat cukup signifikan dibanding tahun 2003 sebesar 3.748 ton, dengan komposisi sampah organik $87,21 \%$, kertas 4,42\%, plastik 5,84\% dan selebihnya alumunium, kaca, kayu dan jenis lainnya. Kapasitas limbah padat Makassar untuk saat ini mencapai $1.860 \mathrm{~m}^{3}$ /hari yang dibuang ke TPA Tamangapa. Timbulan sampah pasar mencapai $60,10 \%$ atau $16,69 \%$ dari total timbulan sampah kota Makassar (STLHD, 2006). Sebagian besar sampah tersebut adalah sampah organik yang berasal dari pedagang sayur-mayur dan buah-buahan serta sisa-sisa makanan, serta dari para pembeli dan pengunjung yang membuang sampah sembarangan. Hal ini diakibatkan bukan saja karena pertambahan jumlah penduduk tetapi juga karena meningkatnya timbulan sampah per kapita yang disebabkan oleh perbaikan tingkat ekonomi dan kesejahteraan.

Pasar sebagai suatu tempat perdagangan merupakan sumber timbulan sampah dan limbah cair dari kawasan komersial. Sebagai sebuah pusat perdagangan, pasar selalu berada di lokasi yang strategis, bahkan banyak dijumpai letak pasar ada di pusat kota. Pasar mempunyai potensi yang cukup besar untuk menimbulkan sampah dan limbah cair. Sementara lahan TPA merupakan permasalahan tersendiri yang dihadapi suatu kota besar. Untuk dapat mengelola sampah dan limbah cair pasar dengan benar, maka awal yang paling penting diketahui adalah pemahaman terhadap kuantitas, wujud, karakteristik dan potensi dari sampah dan limbah cair yang akan dikelola.

Meningkatnya volume sampah yang dihasilkan oleh masyarakat urban maupun dari aktivitas pasar. Sementara itu, rendahnya pengetahuan, kesadaran, dan partisipasi pedagang dalam pengelolaan sampah menjadi suatu permasalahan yang perlu mendapat perhatian dalam pengelolaan lingkungan bersih dan sehat. Kegiatan pengolahan sampah pasar selama ini relatif belum melibatkan masyarakat sebagai akibat dari kebijakan pemerintah daerah yang bersifat top down. Salah satu indikatornya adalah kebijakan tarif retribusi kebersihan hanya ditentukan oleh aparatur pemerintah daerah dan relatif belum memperhatikan aspirasi masyarakat menyangkut berapa sesungguhnya para pedagang bersedia membayar untuk mendukung kegiatan pengolahan sampah di lingkungannya.

Awal munculnya isu tentang pengelolaan sampah pasar terakit dengan meningkatnya volume timbulan sampah pasar sebagai akibat dari pola penanganan yang konvensional dari Dinas Pengolaan Lingkungan Hidup dan Kebersihan (DPLHK) Kota Makassar. Permasalahan persampahan di beberapa pasar tradisional besar seperti Pasar Pabbaeng-baeng dan Pasar Terong, hanya berkisar pada aspek teknis operasional yaitu sistem pewadahan dan pengangkutan yang tidak memadai, serta peran serta masyarakat khususnya pedagang masih kurang dalam penanganan sampah pasar. Kurangnya kesadaran dan perhatian para pedagang mengakibatkan mereka membuang sampah sembarangan, sehingga mengotori kanal, di sekitar tempat jualan pedagang, bahkan di ruas jalan menuju pasar juga terlihat tumpukan sampah. Hal ini menimbulkan kesan kekumuhan, pencemaran bau dan merusak wajah pasar itu sendiri serta mengganggu kesehatan. Hal inilah yang memicu para pemangku kepentingan seperti Assosiasi Pedagang Pasar, partai politik, media massa, LSM, dan kalangan perguruan tinggi untuk melemparkan isu tentang penataan pasar tradisional, terutama sekali pada aspek pengelolaan sampah pasar. 
Meluasnya isu penataan pasar tradisional dari hasil interaksi antar kelompok kepentingan, partai politik, media massa, dan pemerintah daerah berimbas pada pembahasan Rancangan Peraturan Daerah (Ranperda) tentang Penataan Pasar Tradisional oleh DPRD Kota Makassar. Isu utama yang menjadi agenda kebijakan adalah hal yang berkaitan dengan sistem dan prosedur pengelolaan sampah pasar. Isu kebijakan revitalisasi pasar tradisional diharapkan tidak hanya terfokus pada aspek penataan spasial (keruangan), tetapi juga memperhatikan aspek sosial dan pengelolaan lingkungan terutama aspek persampahan.

\section{2) Perumusan Masalah}

Permasalahan yang akan di bahas dalam kajian ini adalah bagaimana proses transformasi isu tentang kekumuhan, timbulan sampah, dan kemacetan di pasar tradisional dapat berkembang menjadi isu agenda kebijakan pada Dewan Perwakilan Rakyat Daerah (DPRD) dan Pemerintah Daerah menyangkut pengelolaan sampah pasar di kota Makasar.

\section{3) Tujuan Penelitian.}

Tujuan kajian ini terkait dengan beberapa hal, yakni: (1.) melakukan identifikasi terhadap proses tranformasi isu publik menjadi isu agenda kebijakan terkait dengan pengelolaan sampah pasar di kota Makasar, (2.) melakukan pemetaan konseptual yang akan memberikan konstribusi dalam hal pengembangan studi formulasi kebijakan publik khususnya mengenai tahapan agenda setting.

\section{B. KAJIAN TEORI}

\section{1) Konsep Isu dan Agenda}

Secara konseptual, suatu masalah privat sebelum masuk ke dalam agenda kebijakan, masalah tersebut menjadi isu terlebih dahulu. Isu ini akan menjadi embrio awal bagi munculnya masalah-masalah publik dan bila masalah tersebut mendapat perhatian yang memadai, maka ia akan masuk ke dalam agenda kebijakan. Sebuah isu atau permasalahan dimulai dari adanya problem isu di tengah- tengah masyarakat. Problem isu ini berawal dari isu yang kecil dan lama-kelamaan mendapat tanggapan dari masyarakat luas (publik), sehingga isu menjadi sebuah pembicaraan di tengah-tengah masyarakat dan menjadi isu publik. Setelah menjadi isu publik, maka tentunya isu ini akan diakomodir oleh kelompok-kelompok kepentingan yang ada untuk disampaikan kepada pembuat kebijakan di daerah untuk menjadi pembahasan bersama. Pembahasan yang terjadi antara pembuat kebijakan (DPRD dan Pemda) tentang isu yang disampaikan oleh kelompokkelompok kepentingan tadi yang menjadi isu agenda kebijakan.

Issues diartikan oleh Cobb \& Elder (1972) sebagai problema publik yang saling bertentangan (konflik) satu sama lain (controversial public problems). Issues dapat diartikan pula sebagai perbedaan-perbedaan pendapat di masyarakat tentang persepsi dan solusi (policy action) terhadap suatu masalah publik. Issues kebijakan tidak hanya mengandung ketidaksepakatan mengenai arah tindakan yang aktual dan potensial, tetapi juga mencerminkan pertentangan panda-ngan mengenai sifat masalah itu sendiri.

Isu-isu yang beredar dalam masyarakat akan bersaing satu dengan yang lain untuk mendapatkan perhatian dari para elit politik, sehingga isu yang mereka perjuangkan dapat masuk ke agenda kebijakan. Oleh karena itu kelompok-kelompok dalam masyarakat akan menggunakan berbagai cara untuk memperjuangkan suatu isu agar masuk ke agenda kebijakan, seperti misalnya memobilisasi diri, mencari dukungan kelompok-kelompok lain maupun menggunakan media massa.

Menurut Cobb dan Elder, (1972 : 82), sebuah isu akan tercipta melalui beberapa cara, yaitu :

- Isu dibuat oleh partai yang merasa melihat ketidakadilan atau bias (penyelewengan) dalam distribusi kekuasaan dan sumber daya.

- Penciptaan isu demi kepentingan dan

- keuntungan personal atau kelompok tertentu.

- Isu tercipta akibat peristiwa yang tidak terduga. 
- Isu dibuat oleh "orang yang selalu ingin perbaikan".

Namun pembentukan isu tidak hanya tergantung kepada satu pemicu saja. Harus ada kaitan antara pemicu dan keprihatinan atau problem yang kemudian 'mengubah isu menjadi item agenda. Agenda tersebut oleh Cobb dan Elder dikarakteristikkan menjadi dua tipe : sitematik dan institusional. Agenda sitematis terdiri dari " semua isu yang umumnya dirasakan oleh anggota komunitas politik sebagai isu yang pantas mendapat perhatian dan dianggap sebagai persolan didalam yurisdiksi yang sah dalam otoritas pemerintah (Cobb dan Elder, 1972 : 85).

Agenda adalah istilah yang pada umumnya digunakan untuk menggambarkan suatu isu yang dinilai oleh publik perlu diambil suatu tindakan. Kegiatan membuat masalah publik (public problems) menjadi masalah kebijakan (policy problems) sering disebut dengan penyusunan agenda (agenda setting). Dengan demikian, "policy agenda" akan memuat masalah kebijakan yang perlu direspons oleh sistem politik yang bersumber dari lingkungan. Agenda sebagai suatu kesepakatan umum, belum tentu tertulis tentang adanya suatu masalah publik yang perlu menjadi perhatian bersama dan menuntut campur tangan pemerintah untuk memecahkannya. Kepemimpinan politik merupakan faktor yang penting dalam penyusunan agenda. Para pemimpin politik mungkin menanggapi, menyebarluaskannya dan mengusulkan penyelesaian terhadap masalah-masalah tersebut. Dalam kaitan ini, Dalam kaitan ini, eksekutif daerah atau Pemerintah Daerah maupun anggota-anggota lembaga legislatif daerah (DPRD) mempunyai peran utama dalam politik dan pemerintahan untuk menyusun agenda publik.

\section{2) Konsep Agenda Setting}

Kebijakan publik adalah suatu upaya yang diambil untuk memecahkan masalahmasalah publik, maka penyusunan kebijakan publik sudah seharusnya (senantiasa) dimulai dari adanya agenda setting yang disusun berdasarkan partisipasi publik. Ini berarti keterlibatan publik dalam penyusunan agenda menjadi sangat penting. Namun demikian cara dan mekanisme penyusunan agenda bagi suatu negara tentu sangat dipengaruhi oleh faktor kondisi politiknya.

Agenda setting (penyusunan agenda) adalah tahap awal dari suatu proses kebijakan publik. Meskipun merupakan tahap awal, tetapi kegiatan menyusun agenda adalah kegiatan yang sulit karena meliputi pengenalan masalah yang benar. Hal ini dikarenakan pembuat kebijakan tidak selalu berhadapan dengan masalah yang akan dipecahkannya (melalui kebijakan yang akan diputuskannya). Meskipun terkadang pembuat kebijakan sudah menemukan "masalah", tetapi belum tentu "masalah" itulah yang paling urgen dan dituntut oleh publik untuk dipecahkan. Apalagi biasanya "masalah" yang muncul itu sangat kompleks dan bervariasi, baik dari segi materinya maupun dari segi asal muasalnya.

Konsepsi agenda yang lebih mendalam ditulis oleh Layne D. Hoppe yang berjudul "Agenda Setting Strategies: Pollution Policy". Menurut Hoppe dalam bukunya yang diterbitkan pada tahun 1969 itu, "Agenda adalah sebuah istilah tentang pola-pola tindakan pemerintahan yang spesifik sifatnya, terutama dalam tahapan awal perkembangan suatu kebijakan. Agenda bisa diartikan sebagai analisis tentang bagaimana suatu problem dikembangkan, didefinisikan, dan diformulasikannya cara-cara untuk pemecahannya" (Cobb \& Elder, 1972).

Roger W. Cobb dan Charles D. Elder (1972) membagi agenda kedalam dua macam, yaitu; Agenda Sistematis (Systemic Agenda), dan Agenda Institusional (Institutional Agenda). Agenda Sistematis adalah agenda yang memuat semua isu yang secara umum dipersepsikan oleh anggota masyarakat politik sebagai masalah publik dan masalahmasalah yang berhubungan dengan kekuasaan pemerintah yang ada. Sedangkan Agenda Institusional adalah serangkaian masalah yang secara eksplisit diangkat oleh lembaga (institusi) pengambil keputusan resmi untuk dijadikan pertimbangan aktif dan serius dalam mengambil keputusan.

Agenda setting dengan demikian disusun berdasarkan perebutan dan perjuangan 
kelompok-kelompok yang ada tersebut, dimana pemerintah dikelilingi oleh pengaruh kelompok-kelompok tersebut. Issues akan mudah tampil atau masuk dalam agenda sistemik menurut Cobb and Elder (1972) jika:

1. Isu itu memperoleh perhatian yang luas atau setidaknya dapat menimbulkan kesadaran masyarakat;

2. Adanya persepsi dan pandangan atau pendapat publik yang luas bahwa beberapa tindakan perlu dilakukan untuk memecahkan masalah itu; dan

3. Adanya persepsi yang sama dari masyarakat bahwa masalah itu merupakan suatu kewajiban dan tanggung jawab yang sah dari beberapa unit pemerintahan untuk memecahkannya.

Isu politik (political issues) yang telah masuk ke dalam agenda pemerintah tadi kemudian masuk ke dalam sistempolitik untuk diproses (digodok) menjadi kebijakan publik. Secara skematis kegiatan agenda setting dapat digambarkan sebagai berikut.

Agenda Setting Process

\begin{tabular}{|l|l|l|}
\hline No & \multicolumn{1}{|c|}{ Tataran } & \multicolumn{1}{|c|}{ Masalah } \\
\hline I. & $\begin{array}{l}\text { Private } \\
\text { Problems }\end{array}$ & $\begin{array}{l}\text { Akibat yang terbatas, atau hanya } \\
\text { menyangkut satu atau sejumlah kecil orang } \\
\text { yang terlibat secara langsung. }\end{array}$ \\
\hline II. & $\begin{array}{l}\text { Public } \\
\text { Problems }\end{array}$ & $\begin{array}{l}\text { Public Problems: adalah masalah-masalah } \\
\text { yang mempunyai akibat lebih luas } \\
\text { termasuk akibat-akibat yang mengenai } \\
\text { orang-orang yang secara tidak langsung } \\
\text { terlibat. }\end{array}$ \\
\hline III. & $\begin{array}{l}\text { Political } \\
\text { Issues }\end{array}$ & $\begin{array}{l}\text { Political issues; adalah perbedaan } \\
\text { pendapat masyarakat tentang solusi dalam } \\
\text { menangani masalah (policy action) }\end{array}$ \\
\hline IV. & $\begin{array}{l}\text { Systemic } \\
\text { Agenda }\end{array}$ & $\begin{array}{l}\text { Systematic Agenda : isu dirasakan oleh } \\
\text { semua warga masyarakat politik yang } \\
\text { patut mendapat perhatian publik dan isu } \\
\text { tersebut berada dalam yuridiksi } \\
\text { kewenangan pemerintah. }\end{array}$ \\
\hline V. & $\begin{array}{l}\text { Institutional } \\
\text { Agenda }\end{array}$ & $\begin{array}{l}\text { Institutional Agenda: serangkaian isu yang } \\
\text { secara tegas membutuhkan pertimbangan } \\
\text { pertimbangan yang aktif dan sering dari } \\
\text { pembuat keputusan yang sah }\end{array}$ \\
\hline
\end{tabular}

SUMBER : COBB \& ELDER, 1972

Agenda institusional atau pemerintah terdiri dari masalah-masalah yang mendapatkan perhatian yang sungguh-sungguh dari pejabat pemerintah. Karena terdapat bermacammacam pokok agenda yang membutuhkan keputusan-keputusan kebijakan maka terdapat pula banyak agenda lembaga. Pada tingkat nasional misalnya, kita akan mendapatkan agenda kepresidenan, agenda administratif, agenda pengadilan dan lain sebagainya. Agenda lembaga merupakan agenda tindakan yang mempunyai sifat lebih khusus dan lebih konkrit bila dibandingkan dengan agenda sistemik.

\section{3) Konsep Pengelolaan Sampah Pasar}

Berdasarkan Undang-Undang No. 18 Tahun 2008, sampah adalah sisa kegiatan sehari-hari manusia dan/atau proses alam yang berbentuk padat. Pengelolaan sampah dimaksudkan adalah kegiatan yang sistematis, menyeluruh, dan berkesinambungan yang meliputi pengurangan dan penanganan sampah. Berdasarkan sifat fisik dan kimianya sampah dapat digolongkan menjadi : 1) sampah ada yang mudah membusuk terdiri atas sampah organik seperti sisa sayuran, sisa daging, daun dan lain-lain; 2) sampah yang tidak mudah membusuk seperti plastik, kertas, karet, logam, sisa bahan bangunan dan lainlain; 3) sampah yang berupa debu/abu; dan 4) sampah yang berbahaya (B3) bagi kesehatan, seperti sampah berasal dari industri dan rumah sakit yang mengandung zat-zat kimia dan agen penyakit yang berbahaya.

Sesuai dengan ketentuan yang ditetapkan pada dalam Pasal 5 UU No.23 Th.1997 tentang Pengelolan Lingkungan Hidup, bahwa masyarakat berhak atas lingkungan hidup yang baik dan sehat. Untuk mendapatkan hak tersebut, pada Pasal 6 dinyatakan bahwa masyarakat dan pengusaha berkewajiban untuk berpartisipasi dalam memelihara kelestarian fungsi lingkungan, mencegah dan menaggulangi pencemaran dan kerusakan lingkungan. Terkait dengan ketentuan tersebut, dalam UU No. 18 Tahun 2008 secara eksplisit juga dinyatakan, bahwa setiap orang mempunyai hak dan kewajiban dalam pengelolaan sampah.

Dalam hal pengelolaan sampah pasal 12 dinyatakan, setiap orang wajib mengurangi dan menangani sampah dengan cara berwawasan lingkungan. Masyarakat juga dinyatakan berhak berpartisipasi dalam 
proses pengambilan keputusan, pengelolaan dan pengawasan di bidang pengelolaan sampah. Cara partisipasi masyarakat dalam pengelolaan sampah dapat dilakukan dengan memperhatikan karakteristik dan tatanan sosial budaya daerah masing-masing. Berangkat dari ketentuan tersebut, tentu menjadi kewajiban dan hak setiap orang baik secara individu maupun secara kolektif, demikian pula kelompok masyarakat pengusaha dan komponen masyarakat lain untuk berpartisipasi dalam pengelolaan sampah dalam upaya untuk menciptakan lingkungan perkotaan dan perdesaan yang baik, bersih, dan sehat.

Menurut Suarna (2008), beberapa pendekatan dan teknologi pengelolaan dan pengolahan sampah yang telah dilaksanakan antara lain adalah:

- Teknologi Komposting

- Teknologi Pembuatan Pupuk Kascing

- Pengolahan sampah menjadi listrik.

- Pengelolaan sampah mandiri

- Pengelolaan sampah berbasis masyarakat

Pola pengelolaan sampah berbasis masyarakat sebaiknya dilakukan secara sinergis (terpadu) dari berbagai elemen (pemerintah, LSM, pengusaha/swasta, sekolah, dan komponen lain yang terkait) dengan menjadikan komunitas lokal sebagai objek dan subjek pembangunan, khususnya dalam pengelolaan sampah untuk menciptakan lingkungan bersih, aman, sehat, asri, dan lestari

\section{METODE PENELITIAN}

\section{1) Tipe \& Desain Penelitian}

Tipe penelitian ini bersifat deskriptif yang bersifat kualitatif dengan mempergunakan data kualitatif maupun kuantitatif. Dalam penelitian kualtitatif, prosedur sampling yang terpenting adalah bagaimana menentukan informan kunci (key informan) yang sarat informasi sesuai dengan fokus penelitian (Bungin, 2003: 53). Mengingat dasar penelitian ini bersifat studi kasus, sehingga metode pengumpulan data akan lebih banyak diadakan dengan instrumen indepth intervieuw dengan key informan yang terpilih.

\section{2) Pendekatan dan Teknik Pengumpulan Data}

Pendekatan Pengambilan data dilakukan dengan metode (Rural Rapid Appraisal) RRA yaitu dengan memahami masyarakat secara cepat. Pendekatan ini sangat kasar dalam metode pengambilan data. Selain itu peneliti juga melakukan pendekatan dengan metode PRA (Participatory Rural Appraisal) yaitu memahami masyarakat secara partisipatif.

Untuk mendapatkan data sekunder dan data primer yang akurat maka penulis menggunakan teknik pengumpulan data sebagai berikut:

\section{Studi Pustaka (Library Research)}

Dalam studi pustaka ini penulis berusaha menelaah berbagai bahan bacaan/pustaka berupa buku-buku, majalah, surat kabar, undang-undang, peraturan pemerintah serta dokumen-dokumen lainnya yang mempunyai relevansi dengan masalah yang akan diteliti.

\section{Studi Lapangan (Field Research)}

Studi lapangan ini dimaksudkan yaitu penulis langsung melakukan penelitian pada lokasi atau obyek yang telah ditentukan. Studi lapangan ditempuh dengan cara sebagai berikut:

a. Wawancara, yaitu mengadakan tanya jawab langsung kepada informan yang memiliki informasi tentang aspek pengelolaan sampah pasar.

a. Focussed Group Discussion (FGD), yaitu teknik pengumpulan melalui disksusi kelompok terarah pada beberapa key informan.

\section{3) Analisa Data}

Data dalam penelitian ini merupakan data primer yang diperoleh dilapang dari hasil wawancara yang mendalam dan FGD dari informan dan key informan. Data yang terkumpul kemudian dianalisis secara deskriptif sesuai dengan tujuan penelitian melalui indikator-indikator yang telah ditetapkan. 


\section{HASIL DAN PEMBAHASAN}

\section{1) Kondisi Eksisting Pengelolaan Sampah Pasar Di Kota Makassar}

Sampah masih menjadi persoalan yang tiada hentinya. Kemampuan dan kapasitas pemerintah yang rendah diperhadapkan dengan kesadaran masyarakat yang masih rendah telah menjadi kombinasi buruk penanganan sampah di kota Makassar. Bahkan sebagian besar masyarakat menganggap bahwa masalah sampah tanggung jawab pemerintah semata. Sebagian masyarakat juga beranggapan sampah bukanlah masalah bila tidak berada di sekitarnya.

Terkait dengan masalah pengelolaan sampah dan upaya menciptakan lingkungan kota yang lebih baik, akhirnya pada tanggal 15 Mei 2004 dicanangkanlah kampanye Makassar bersih oleh Walikota Makassar, yang bertujuan menggugah kesadaran masyarakat dan menciptakan tanggung jawab bersama terhadap permasalahan sampah di kota Makassar (Status Lingkungan Hidup daerah Kota Makassar, 2006). Selain itu, sejak tahun 2008 pemerintah kota Makassar juga mencanangkan Program Makassar Grean and Clean untuk menuju Makassar Bersih. Namun upaya ini, tidak akan berhasil sepenuhnya tanpa adanya dukungan dari masyarakat.

Sampah merupakan salah satu ekses dari kegiatan penduduk, baik sampah padat, cair dan gas yang berasal dari kegiatan rumah tangga, industri dan kegiatan perkotaan lainnya. Data mengenai kondisi umum persampahan di kota Makassar pada Tahun 2008 disajikan pada tabel 01.

Secara umum, dari data kondisi lokasi sumber sampah memperlihatkan bahwa beberapa lokasi mampu mengelola sampahnya secara keseluruhan. Pada lokasi-lokasi tersebut, misalnya permukiman mewah, pantai wisata dan kawasan perkantoran dapat dikatakan bahwa timbulan sampah yang terjadi setiap hari, hampir seluruhnya dapat diangkut ke Tempat Pembuangan Akhir (TPA). Sebaliknya, data juga memperlihatkan bahwa beberapa lokasi di kota Makassar belum mampu menangani timbulan sampah dengan cara mengangkutnya ke TPA.

Berdasarkan tabel 01, sumber sampah terbesar adalah dari permukiman sederhana yang ada di Kota Makassar. Dari total timbulan sampah harian, rata-rata persentase sampah yang terangkut dan dibuang ke TPA berjumlah sekitar 1093,29 $\mathrm{m}^{3}$ /hari. Sedangkan total

Tabel No.01. Timbulan Sampah Dan Yang Terangkut Di Kota Makassar Tahun 2008

\begin{tabular}{|c|c|c|c|c|c|}
\hline No. & Lokasi & $\begin{array}{l}\text { Timbulan } \\
\left(\mathrm{M}^{3} / \text { hari }\right)\end{array}$ & $\begin{array}{l}\text { Persentase Terhadap } \\
\text { Total Timbulan }\end{array}$ & $\begin{array}{c}\text { Sampah Terangkut } \\
\left(M^{3} / \text { hari }\right)\end{array}$ & $\begin{array}{l}\text { Persentase Terhadap } \\
\text { Total Timbulan }\end{array}$ \\
\hline \multirow[t]{4}{*}{1.} & Pemukiman: & & & & \\
\hline & a. Mewah & 244,67 & 6,42 & 231,29 & $94,53 \%$ \\
\hline & b. Menengah & 371,35 & 9,74 & 325,30 & $87,60 \%$ \\
\hline & c. Sederhana & 1282,45 & 33,64 & 1093,29 & $85,25 \%$ \\
\hline \multirow[t]{10}{*}{2.} & Fasilitas Kota : & & & & \\
\hline & a. Pasar & 574,80 & 15,08 & 492,55 & $85,69 \%$ \\
\hline & b. Kawasan Perniagaan & 158,80 & 4,16 & 139,37 & $87,93 \%$ \\
\hline & c. Kawasan Perkantoran & 135,12 & 3,54 & 124,77 & $92,34 \%$ \\
\hline & d. Kawasan Pendidikan & 98,40 & 2,58 & 86,22 & $87,62 \%$ \\
\hline & e. Terminal & 98,00 & 2,57 & 80,66 & 82,31 \\
\hline & f. Pelabuhan & 88,00 & 2,31 & 80,29 & $91,24 \%$ \\
\hline & g. Hotel & 94,57 & 2,48 & 81,86 & $86,56 \%$ \\
\hline & h. Rumah Sakit & 93,00 & 2,44 & 80,78 & $86,86 \%$ \\
\hline & i. Sarana Ibadah & 42,31 & 1,11 & 37,51 & 88,65 \\
\hline 3. & Kawasan Industri & 86,92 & 2,28 & 75,93 & $87,36 \%$ \\
\hline 4. & Perairan Terbuka & 281,80 & 7,39 & 238,54 & $84,65 \%$ \\
\hline 5. & Pantai Wisata & 14,80 & 0,39 & 13,88 & 93,80 \\
\hline 6. & Sapuan Jalan \& Taman & 116,00 & 3,04 & 104,69 & $90,25 \%$ \\
\hline 7. & Lain-lain & 32,00 & 0,84 & 28,27 & $88,34 \%$ \\
\hline \multicolumn{2}{|c|}{ Total Timbulan Sampah Kota } & 3.812 .69 & 100 & $3.315,20$ & $86,95 \%$ \\
\hline
\end{tabular}


timbulan adalah $1.282,45 \mathrm{~m}^{3} /$ hari, sehingga total timbulan yang tidak terangkut adalah sebesar $189,16 \mathrm{~m}^{3} /$ hari atau berkisar $14 \%$.

Tabel No.02.

Komposisi Sampah Di Kota Makassar Periode Desember 2008

\begin{tabular}{|c|l|r|r|}
\hline No. & Komposisi Sampah & Volume $\left(\mathbf{M}^{3}\right)$ & Persentase \\
\hline 1. & Sampah Organik & 3.187 .79 & $83.61 \%$ \\
\hline 2. & Kertas, Karton & 251,26 & $6,59 \%$ \\
\hline 3. & Plastik & 258.50 & $6.78 \%$ \\
\hline 4. & Metal, Kaleng, Besi, Aluminium & 62,15 & $1,63 \%$ \\
\hline 5. & Karet. Ban & 35.08 & $0.92 \%$ \\
\hline 6. & Kaca & 9,15 & $0,24 \%$ \\
\hline 7. & Kayu & 6.86 & $0.18 \%$ \\
\hline 8. & Lain-Lain & 1,91 & $0,05 \%$ \\
\hline Jumlah & $3.812,69$ & $100,00 \%$ \\
\hline
\end{tabular}

Sumber Data : Dinas Pengelolaan Lingkungan Hidup \& Keindahan Kota Makassar, 2009

Berdasarkan tabel No. 02 di atas, komposisi terbesar sampah di kota Makassar Periode Desember 2008 adalah sampah organik (bio waste) yang layak kompos sebesar 83,61 \%, dan yang terkecil adalah komposisi sampah kayu sebesar 0,18 \%. Sampah organik dengan proporsinya yang terbesar, merupakan permasalahan utama persampahan di kota Makassar ; bila tidak dikelola dengan baik, sampah organik dapat menjadi sumber pencemar lingkungan yang potensial.

Berbeda dengan sampah organik, sampah anorganik pada batas-batas tertentu, melalui mekanisme pasar, dapat digunakan kembali sebagai bahan baku industri (Kementrian Negara Lingkungan Hidup-JICA, 2008), kecuali jenis-jenis sampah anorganik yang sulit didaurulang atau terlalu mahal biaya pendaur ulangannya, misalnya kantong-kantong plastik atau kemasan-kemasan makanan instan.

Sistem pelayanan pembuangan sampah di kota Makassar saat ini sudah dilayani oleh armada sampah yang pengelolaannya berada di bawah naungan Dinas Pengelolaan Lingkungan Hidup dan Keindahan Kota Makassar, mulai dari daerah permukiman, daerah perdagangan, pusat pemerintahan, lokasi kegiatan sosial dan pendidikan. Sistem pengelolaan sampah di kota Makassar pada umumnya menekankan pendekatan Kumpulangkut-buang dan sistem pembuangan di TPA secara terbuka (open dumping).

Dari keseluruhan TPA menerapkan sistem pembuangan terbuka, sekitar $60 \%$ memiliki lokasi TPA yang dapat digolongkan sebagai unmanaged disposal sites. Bahkan, di wialayah tertentu seperti Kalimantan dan Sulawesi, terdapat beberapa kota kecil yang memiliki tempat pembuangan akhir yang sulit dikategorikan sebagai TPA (uncategorized disposal sites). Sistem pengelolaan sampah yang dilakukan dengan cara pembuangan terbuka mengindikasikan bahwa di kota tersebut tidak dilakukan upaya pemilahan sampah. Dengan sistem open dumping, kemampuan pengelola untuk mengangkut sampah cenderung menurun atau realtif tetap. Di sisi lain, jumlah penduduk menunjukkan gejala yang semakin meningkat. Hal ini menyebabkan volume timbulan sampah meningkat, sementara kemampuan mengangkut sampah relative tidak berubah (Status Lingkungan Hidup Daerah, 2006).

Pengelolaan pasar di kota Makassar, umumnya dilakukan oleh perusahaan daerah Pasar (PD Pasar) dan kepemilikan kios/toko secara perorangan. Salah satu permasalahan pada pasar di kota Makassar adalah masalah pengelolaan sampah. Pasar-pasar di kota Makassar menghasilkan sampah dalam jumlah yang besar yaitu sekitar $574,80 \mathrm{~m}^{3} /$ hari. Atau sumber penyumbang sampah kedua terbesar di kota Makassar setelah permukiman sederhana.

Sebagian besar sampah tersebut berasal dari pedagang, konsumen, baik dari barangbarang yang dijual di pasar berupa kemasan, kulit sayur, atau sisa olahan barang yang akan dijual. Komposisi sampah dari sampah pasar kota Makassar adalah berupa sampah organik dan anorganik. Sampah organik terbesar bersumber dari sayur mayur. Sedangkan sampah anorganik biasanya dari kemasan barang dagangan berupa kantung plastik, karung, kertas, dsb.

Dalam pengelolaan persampahan skala kota yang rumit, terdapat beragam stakeholders yang teribat secara langsung ataupun tidak langsung. Setiap stakeholders berperan sesuai dengan posisinya masing-masing. Dalam skala kota, peran pemerintah kota dalam mengelola sampah sangat-lah penting, dan pengelolaan sampah merupakan salah satu tugas utamanya sebagai bentuk pelayanan yang merupakan 
bagian dari infrastruktur kota tersebut. Stakeholders utama yang terdapat dalam pengelolaan sampah pasar adalah pengelola kota dalam hal ini dilakukan oleh Dinas Pengelolaan Lingkungan Hidup dan Keindahan Kota Makassar.

\section{2) Tahapan Penyusunan Agenda}

Sistem pengelolaan sampah konvensional yang masih berdasarkan prinsip KumpulAngkut-Buang dan sepenuhnya tergantung dari keberadaan TPA, diperkirakan bahwa dalam 510 tahun ke depan, pengelolaan sampah di banyak kota di Indonesia akan mengalami persoalan dengan habisnya masa pakai TPA sementara lokasi pengganti semakin sulit diperoleh sehubungan dengan terbatasnya lahan dan meningkatnya resistensi masyarakat terhadap keberadaan TPA, khususnya yang terletak di sekitar permukiman penduduk (Status Lingkungan Hidup, 2006).

Pada situasi seperti inilah maka upaya menemukenali sebuah tahapan penyusunan agenda dalam pengelolaan sampah pasar di Kota Makassar menjadi sangat isu yang strategis. Transformasi isu menjadi isu agenda kebijakan merupakan produk dari sebuah interaksi antar aktor dan stakeholders dalam menyusun formulasi kebijakan pengelolaan sampah pasar di Kota Makassar. Secara kenseptual dapat di lihat dalam tabel no. 3 di bawah ini.

Tabel No. 03 Matriks Agenda Setting Pengelolaan Sampah Pasar di Kota Makassar

\begin{tabular}{|c|c|c|}
\hline No. & Tataran & Masalah \\
\hline 1. & $\begin{array}{l}\text { Private } \\
\text { Problem }\end{array}$ & $\begin{array}{l}\text { - Timbulan sampah pasar } \\
\text { mengganggu aktivitas jual-beli } \\
\text { - Pendapatan pedagang pasar } \\
\text { menurun }\end{array}$ \\
\hline 2. & $\begin{array}{l}\text { Public } \\
\text { Problem }\end{array}$ & $\begin{array}{l}\text { - Timbulan sampah pasar menyumbat } \\
\text { drainase yang berakibat banjir } \\
\text { - Kualitas lingkungan menjadi } \\
\text { tercemar } \\
\text { - Timbulan sampah yang berserakan } \\
\text { dijalan sekitar pasar, memacetkan } \\
\text { lalu lintas }\end{array}$ \\
\hline 3. & $\begin{array}{l}\text { Policy } \\
\text { Issues }\end{array}$ & $\begin{array}{l}\text { - Perlu metode 3R (Reduce, Reuse, } \\
\text { Recycle) dalam penanganan } \\
\text { sampah pasar } \\
\text { - Peningkatan jumlah fasilitas } \\
\text { persampahan, terutama bak dan } \\
\text { angkutan } \\
\text { - Pembinaan pedagang pasar }\end{array}$ \\
\hline 4. & $\begin{array}{l}\text { Systemic } \\
\text { Agenda }\end{array}$ & $\begin{array}{l}\text { - Revitalisasi manajemen pasar } \\
\text { tradisional } \\
\text { - Partisipasi pedagang dalam } \\
\text { pengelolaan sampah pasar }\end{array}$ \\
\hline 5. & $\begin{array}{l}\text { Intitusional } \\
\text { Agenda }\end{array}$ & $\begin{array}{l}\text { - Partisipasi pedagang dalam } \\
\text { pengelolaan sampah pasar }\end{array}$ \\
\hline
\end{tabular}

\section{Private Problem}

Pasar sebagai suatu tempat perdagangan merupakan sumber timbulan sampah dan limbah cair dari kawasan komersial. Sebagai sebuah pusat perdagangan, pasar selalu berada di lokasi yang strategis, bahkan banyak dijumpai letak pasar ada di pusat kota. Pasar mempunyai potensi yang cukup besar untuk menimbulkan sampah dan limbah cair. Sementara lahan TPA (tempat pembuangan akhir) merupakan permasalahan tersendiri yang dihadapi suatu kota besar. Untuk dapat mengelola sampah dan limbah cair pasar dengan benar, maka awal yang paling penting diketahui adalah pemahaman terhadap kuantitas, wujud, karakteristik dan potensi dari sampah dan limbah cair yang akan dikelola.

Meningkatnya volume sampah yang dihasilkan oleh masyarakat urban maupun dari aktivitas pasar. Sementara itu, rendahnya pengetahuan, kesadaran, dan partisipasi pedagang dalam pengelolaan sampah menjadi suatu permasalahan yang perlu mendapat perhatian dalam pengelolaan lingkungan bersih dan sehat. Kegiatan pengolahan sampah pasar selama ini relatif belum melibatkan masyarakat sebagai akibat dari kebijakan pemerintah daerah yang bersifat top down. Salah satu indikatornya adalah kebijakan tarif retribusi kebersihan hanya ditentukan oleh aparatur pemerintah daerah dan relatif belum memperhatikan aspirasi masyarakat menyangkut berapa sesungguhnya para pedagang bersedia membayar untuk mendukung kegiatan pengolahan sampah di lingkungannya.

Pola penanganan masalah sampah yang cenderung reaktif dan parsial terbukti tidak mampu menyelesaikan problem sampah pasar ini secara holistik. Pada saat yang sama, akibat nyata yang ditimbulkan telah membawa terganggunya aktivitas penjual dan pembeli dalam aktivitas transaksi jual-beli. Kondisi sampah yang berserakan membuat pembeli akan tidak nyaman untuk berbelanja di pasar tradisonal. Pada saat yang sama, semakin maraknya serbuan pasar retail modern yang menawarkan kenyamanan dan kebersihan, membuat pengujung pasar tradisional menjadi semakin berkurang. Dengan semakin 
berkurangnya frekuensi kunjungan pembeli ke pasar tradisonal, maka secara agregat pendapatan pedagang pasar pun menjadi menurun.

\section{Public Problem}

Sampah telah menjadi masalah yang besar, bagi kota-kota besar di Indonesia seperti Jakarta, Surabaya, termasuk Makassar. Cakupan pelayanan pengelolaan persampahan yang masih rendah khususnya di perkotaan dapat berdampak pada meningkatnya wabah penyakit menular seperti tipus, kolera, muntaber, disentri, pes, leptospirus, salmonelosis, demam gigitan tikus. Selain itu, sampah yang dibuang ke kanal dan saluran pembuangan berpotansi menimbulkan banjir.

Volume sampah di Makassar tahun 2004 tercatat 4.330 ton perhari, jumlah ini meningkat cukup signifikan dibanding tahun 2003 sebesar 3.748 ton, dengan komposisi sampah organik $87,21 \%$, kertas $4,42 \%$, plastik $5,84 \%$ dan selebihnya alumunium, kaca, kayu dan jenis lainnya. Kapasitas limbah padat Makassar untuk saat ini mencapai $1.860 \mathrm{~m}^{3} /$ hari yang dibuang ke TPA Tamangapa. Timbulan sampah pasar mencapai $60,10 \%$ atau 16,69 \% dari total timbulan sampah kota Makassar (STLHD, 2006). Sebagian besar sampah tersebut adalah sampah organik yang berasal dari pedagang sayur-mayur dan buahbuahan serta sisa-sisa makanan, serta dari para pembeli dan pengunjung yang membuang sampah sembarangan, tentu akan membuat kualitas lingkungan menjadi tercemar. Hal ini diakibat-kan bukan saja karena pertambahan jumlah penduduk tetapi juga karena meningkatnya timbulan sampah per kapita yang disebabkan oleh perbaikan tingkat ekonomi dan kesejahteraan.

Sampah organik yang umumnya berasal dari sisa sayur-sayuran dan buah-buahan serta kantong kemasan berbahan plastik, yang tidak terangkut dengan di Tempat Pembuangan Sementara (TPS) sekitar pasar menjadi berserakan hingga ke saluran drainase dan kanal. Timbulan sampah yang menyumbat drainase dan kanal, pada musim penghujan dapat menimbulkan banjir. Selain menimbulkan banjir, timbulan sampah yang tidak terangkut dengan cepat di bak sampah, yang juga difungsikan sebagai Tempat Pembuangan Sementara (TPS) hingga ke badan jalan secara nyata telah menimbulkan kemacetan lalu lintas.

\section{Policy Issues}

Selama ini, metode pengelolaan sampah pasar yang diterapkan pemerintah kota terhadap pasar tradisional masih bersifat konvensional. Pola kumpul-angkut-buang/ bakar sebenarnya sudah tidak memadai lagi ditengah upaya peningkatan nilai ekonomi dari sampah. Metode 3R (reduce, reuse, recycle) yang memungkinkan terjadinya daur-ulang sampah secara berkelanjutan. Dengan metode ini, sampah bukan lagi barang yang tidak berguna tetapi menjadi sebuah komoditi yang bernilai ekonomi tinggi.

Permasalahan pengelolaan sampah terutama di Pasar Pabbaeng-baeng dan Pasar Terong terutama pada teknis operasional yaitu sistem pewadahan dan pengangkutan yang tidak memadai, serta peran serta masyarakat khususnya pedagang masih kurang dalam penanganan sampah pasar. Selama ini, pilihan metode konvensional yang digunakan tidak ditunjang oleh jumlah fasilitas persampahan yang memadai. Bak sampah yang berfungsi TPS dan mobil angkutan sampah jumlahnya sangat tidak proporsional dengan laju pertumbuhan sampah yang ada.

Disamping itu, aspek maintainance (pemeliharaan) terhadap fasilitas yang ada serta jumlah personil operator kebersihan juga belum pada kategori yang memadai. Dinas Pengolaan Lingkungan Hidup dan Keindahan (DPLHK) Kota Makassar, sebagai leading sector penanganan masalah ini masih diperhadapkan pada problem birokrasi kronis, seperti keterbatasan dari sisi anggaran, personil hingga pada resistensi terhadap perubahan metode pengeloaan sampah.

Keseluruhan problem yang dihadapi dari sisi manajemen, pada saat yang sama tidak di dukung oleh kesadaran yang tinggi dari kalangan pedangang, terutama dalam mengumpulkan sampah dagangannya. Kurangnya kesadaran dan perhatian para pedagang mengakibatkan mereka membuang 
sampah sembarangan, sehingga mengotori kanal, di sekitar tempat jualan pedagang, bahkan di ruas jalan menuju pasar juga terlihat tumpukan sampah. Situasi ini seharusnya menyadarkan pemerintah kota bahwa perbaikan manajemen sampah pasar tidaka bisa dilakukan hanya dengan memperbaiki sarana dan prasarana saja. Perlu sentuhan pada aspek manusianya, dalam hal ini peningkatan kesadaran melalui pembinaan pedagang untuk berperan dalam mengelola sampah pasar.

\section{Systemic Agenda}

Sampah masih menjadi persoalan yang tiada hentinya. Kemampuan dan kapasitas pemerintah yang rendah diperhadapkan dengan kesadaran masyarakat yang masih rendah telah menjadi kombinasi buruk penanganan sampah di kota Makassar. Sebagian masyarakat juga beranggapan sampah bukanlah masalah bila tidak berada di sekitarnya.

Terkait dengan masalah pengelolaan sampah dan upaya menciptakan lingkungan kota yang lebih baik, akhirnya pada tanggal 15 Mei 2004 dicanangkanlah kampanye Makassar bersih oleh Walikota Makassar, yang bertujuan menggugah kesadaran masyarakat dan menciptakan tanggung jawab bersama terhadap permasalahan sampah di kota Makassar (Status Lingkungan Hidup daerah Kota Makassar, 2006). Selain itu, sejak tahun 2008 pemerintah kota Makassar juga mencanangkan Program Makassar Grean and Clean (MGC) untuk menuju Makassar Bersih. Namun upaya ini, tidak akan berhasil sepenuhnya tanpa adanya dukungan dari masyarakat.

Secara umum, kini fungsi pasar bertransformasi dari fungsi sebagai arena transaksi menjadi fungsi produsen sampah, penyebab banjir, dan kemacetan. Langkah sistemik yang diharus dilakukan pemerintah kota adalah dengan segera melakukan langkah revitalisasi pasar tradisional, dari sisi manajemen dan penataan fisik. Langkah in diharapkan akan mengembalikan fungsi pasar tradisional sebagai arena jual-beli yang egaliter serta menghadirkan suasana nyaman dan bersih, dan mampu bersaing pasar retail modern yang semakin menjamur.

Partisipasi pedagang dalam pengelolaan sampah pasar menjadi sebuah keniscayaan. Hal ini terkait dengan kesadaran bahwa di era new governance, pemangku kepentingan utama pembangunan buka hanya di sektor pemerintah. Anggapan sebagian besar masyarakat menganggap bahwa masalah sampah tanggung jawab pemerintah semata perlu direorientasikan. Dalam pola interaksi new governance, pedagang tidak lagi diposisikan hanya sebagi obyek pasif yang hanya bisa memproduksi sampah dan membayar retribusi, tetapi menjadi bagian dan aktor penting dalam pengelolaan sampah pasar. Partisipasi pedagang dapat dilakukan mulai dilevel penyusunan rencana (perencanaan), tindakan pelaksanaan, hingga ditahap monitoring (pengawasan).

\section{Institutional Agenda}

Dari total timbulan sampah harian, ratarata persentase sampah yang terangkut dan dibuang ke TPA berjumlah sekitar 1093,29 $\mathrm{m}^{3} /$ hari. Sedangkan total timbulan adalah $1.282,45 \mathrm{~m}^{3} /$ hari, sehingga total timbulan yang tidak terangkut adalah sebesar 189, 16 $\mathrm{m}^{3}$ /hari atau berkisar $14 \%$ (DPLHK, 2009). Sistem pelayanan pembuangan sampah di kota Makassar saat ini sudah dilayani oleh armada sampah yang pengelolaannya berada di bawah naungan Dinas Pengelolaan Lingkungan Hidup dan Keindahan Kota Makassar, mulai dari daerah permukiman, daerah perdagangan, pusat pemerintahan, lokasi kegiatan sosial dan pendidikan. Sistem pengelolaan sampah di kota Makassar pada umumnya menekankan pendekatan Kumpulangkut-buang dan sistem pembuangan di TPA secara terbuka (open dumping).

Dalam pengelolaan persampahan skala kota yang rumit, terdapat beragam stakeholders yang teribat secara langsung ataupun tidak langsung. Setiap stakeholders berperan sesuai dengan posisinya masingmasing. Dalam skala kota, peran pemerintah kota dalam mengelola sampah sangatlah penting, dan pengelolaan sampah merupakan salah satu tugas utamanya sebagai bentuk 
pelayanan yang merupakan bagian dari infrastruktur kota tersebut.

Stakeholders utama yang terdapat dalam pengelolaan sampah pasar adalah Dinas Pengelolaan Lingkungan Hidup dan Keindahan Kota Makassar dengan Pedagang pasar. Hubungan kemitraan antar kedua aktor dan kelembagaan ini menjadi solusi dalam mengatisipasi laju pertumbuhan aktivitas ekonomi pasar yang menghasilkan ribuan ton meter-kubik jumlah sampah. Dari titik inilah, upaya mendorong perluasan partsipasi pedagang dalam pengelolaan sampah pasar penting untuk menjadi agenda kebijakan Pemerintah Kota Makassar.

\section{E. KESIMPULAN DAN SARAN}

\section{1) Kesimpulan}

Sampah telah menjadi masalah yang besar, bagi kota-kota besar di Indonesia seperti Jakarta, Surabaya, Bandung dan termasuk Makassar. Timbulan sampah pasar mencapai $60,10 \%$ atau $16,69 \%$ dari total timbulan sampah kota Makassar (STLHD, 2006). Cakupan pelayanan pengelolaan persampahan yang masih rendah khususnya di perkotaan dapat berdampak pada menurunnya aktivitas ekonomi pada pasar tradisional serta memicu peningkatan penyakit menular seperti diare, disentri, pes, dll.

Berdasarkan hasil pembahasan diatas, maka dapat ditarik kesimpulan yakni Sistem pengelolaan sampah yang selama ini diterapkan di Pasar belum memberikan hasil yang optimal karena kurangnya ketersediaan TPS, pengangkutan sampah ke TPA belum dilaksanakan secara rutin, penyediaan infrastruktur persampahan yang masih minim oleh instansi terkait. Sementara Partisipasi pedagang masih rendah, ditandai dengan kurangnya keterlibatan pedagang mulai dari tahap perencanaan, pelaksanaan dan pengawasan pengelolaan sampah. Untuk itulah penyusunan agenda kebijakan pengelolaan sampah pasar penting untuk dilakukan.

\section{2) Saran}

- Setiap pasar dianjurkan menggunakan tempat sampah dua partisi dan dilakukan pemilahan pada tahap awal dan sampah yang ada (organik) dibuat kompos. Untuk pengadaan bahan dan peralatannya dapat disediakan dan dibantu oleh pihak pengelola pasar kerjasama dengan pihak pemerintah.

- Pemerintah Kota Makassar, yakni Dinas Pengelolaan Lingkungan Hidup dan Keindahan agar meningkatkan infrastruktur pengelolaan sampah baik itu berupa penambahan jumlah bak tempat pembuangan sampah sementara (TPS) di pasar, penambahan jumlah petugas kebersihan, maupun peningkatan jumlah armada pengangkutan sampah, sehingga sampah yang tidak dapat ditangani dapat diangkut secara keseluruhan ke tempat pembuangan sampah akhir (TPA).

- Pemerintah Kota Makassar mesti melakukan pembenahan serius terhadap fasilitas persampahan, terutama pada kondisi pasar pascarevitalisasi. Sistem dan penyediaan fasilitas tersebut melibatkan partisipasi pedagang. Pendekatan secara partisipatif dalam perencanaan, pengadaan dan pemeliharaan fasilitas akan meningkatkan rasa memiliki di kalangan pedagang pasar.

- Peraturan Daerah (Perda) tentang penataan Pasar Tradisional perlu dipercepat pembahasan dan atau pemberlakuannya, terutama hal yang berkaitan dengan sistem dan prosedur pengelolaan sampah pasar. Gagasan dan kebijakan revitalisasi pasar tradisional diharapkan tidak hanya terfokus pada aspek penataan spasial (keruangan), tetapi juga memperhatikan aspek sosial dan pengelolaan lingkungan terutama aspek persampahan.

\section{DAFTAR PUSTAKA}

Birkland, Thomas A. 1997. Efter Disaster: Agenda Setting, Public Policy, and Focusing Event, Washington : George Town University Press.

Cobb, Roger. W. \& Charles. D. Elder, 1972.

Participation in American Politics: The Dynamics of Agenda-Building, John Hopkins University Press.

DPLHK, 2009. Komposisi Sampah Di Kota 
Makassar Periode Desember 2008, Laporan Bulanan Dinas Pengeloaan Lingkungan Hidup \& Keindahan Kota Makassar

Dye, Thomas, R. 2005. Understanding Public Policiy (ed. $7^{\text {th }}$ ). New Jersey: Pearson Prentice Hall

Gupta, Dipak K. 2001. Analyzing Public Policy, Concepts, Tools, and Techniques, Singapore : CQ Press.

Kementrian Negara Lingkungan Hidup, 2008. Statistik Persampahan Indonesia. Japan International Cooperation Agency (JICA), Jakarta.

Kingdon, John W. 1995. Agendas, Alternatives, and Public Policies, $2^{\text {nd }}$ ed. New York :
Harper Collins

Status Lingkungan Hidup Daerah (SLHD). 2006, Melaui Makassar Bersih, Menuju Kota Berkelanjutan, Buku Parameter Basis Data, Makassar : Dinas PLHK \& CV. Globalindo Konsultama.

Shinichi Shigetomi, (2002), "The State and NGOs: Issue \&Analytical Framework", dalam Shinichi Shigetomi (ed.), 2002. The State \& NGOs: Perspective from Asia, Singapore: ISEAS.

Stone, Deborah. 2002. Policy Paradox : The Art of Political Decision Making. Rev. ed. New York: W.W Norton)

Undang-Undang No. 18 Tahun 2008 tentang Pengelolaan Sampah. 